\title{
2
}

\section{'We Are Recreating Bedlam': A History of Mental Illness and Prison Systems in England and Ireland}

\section{Catherine Cox and Hilary Marland}

In May 2014, the Guardian newspaper reported a number of shocking instances of homicide carried out by prison inmates suffering from mental health problems. The article went on to accuse the English prison system of 'recreating Bedlam', with a prison service poorly equipped to deal with the $10 \%$ of the prison population who were suffering from serious mental health disorders at any one time. ${ }^{1}$ Unable to protect their mentally ill inmates from self-harm or from harming other prisoners, mental health support in some prisons was described as 'virtually non-existent' and mental health disorders were 'often viewed by management as a discipline problem rather than a health issue' (Sloan and Allison 2014). The Bradley Report of 2009, investigating the provision of mental health services in prison, had urged the

\section{C. $\operatorname{Cox}(\square)$}

University College Dublin, Dublin, Ireland

e-mail: catherine.cox@ucd.ie

H. Marland

University of Warwick, Coventry, UK

e-mail: Hilary.Marland@warwick.ac.uk

(C) The Author(s) 2018 
'earliest possible diversion of offenders with mental disorders from the criminal justice system' (Bradley 2009, p. 53). Yet, little progress had been made by 2014 and mentally ill prisoners were still ending up in prison rather than hospital (Sloan and Allison 2014).

The issues identified by the Guardian are of long standing and have been reiterated time and again in recent inquires and in the press. In 2013, the Irish Times highlighted the damage caused by solitary confinement and described how reports over the past decade, conducted by Irish and international agencies, 'blamed prison conditions for incubating psychological problems that then spill over into self-harming or troubling behaviour' (Humphreys 2013). In 2005, the United Nation's special rapporteur observed that 'overcrowding, lack of privacy, enforced isolation and violence tend to exacerbate mental disabilities' and noted the limited access to basic mental healthcare and support services in Irish prisons (Humphreys 2013). Despite numerous initiatives to reform prisons and their regimes, prisons continue to confine large numbers of people with mental health problems who they are poorly equipped to care for.

Historically, prisons have consistently admitted large numbers of mentally ill people and have been charged with producing and exacerbating mental disorder amongst their inmates, and offering little in the way of treatment. Already by the sixteenth and seventeenth centuries, bridewells and houses of correction were confining 'more dangerous or troublesome lunatics' (Seddon 2007, p. 2) and prison reformer John Howard described how by the late eighteenth century, 'rooms which were designed for prisoners are occupied by lunatics', who were exposed to overcrowded and offensive conditions and denied treatment and proper care (Howard 1780, p. 10). Howard particularly singled out Irish prisons for their poor implementation of legislation intended to preserve the health of prisoners (Howard 1784, p. 205). Referring to the condition of 'lunatics' held at Lancaster Castle prison in the north of England in the first decade of the nineteenth century, penal reformer James Neild described how, violent and often dangerous, they posed a threat to prison order and put prison officers' lives at risk. Neild's suggestion that they be removed to a hospital or place of seclusion went unheeded, however, and in 1812, after one suicide attempt 
and a number of violent skirmishes with the prison warders, one of the 'lunatic' prisoners, James Rawlinson, was found hanged in his cell ${ }^{2}$ (Neild 1812, p. 329; DeLacy 1986, pp. 116-119).

Since the mid-nineteenth century, government inquiries and the reports of prison reform organisations have urged change in the provision of mental health services in prison, while the appropriateness of prison for inmates suffering from mental health problems has been questioned time and again. Prisons have sought to improve their response to treating mentally ill inmates, but these efforts have been hampered by the tensions between the provision of care and need to manage and discipline, and more recently by a lack of viable alternatives in terms of psychiatric services outside the prison system. This essay explores the relationship between the prison and mental illness from the mid-nineteenth century onwards, as a new system of prison discipline was imposed across the British Isles. Our focus lies with England and Ireland, which enables us to trace the introduction of the system of separate confinement at Pentonville Prison in London and then within England, and efforts to respond to and modify the regime in Ireland.

In the first section, we examine the introduction of the system of separate confinement, which, even as it was being introduced, was strongly critiqued for its production of mental disorder. Yet, it endured and support for the separate system proved remarkably resilient. Moving to the late nineteenth century, we seek to explain the persistence of regimes that confined and failed to treat mentally ill prisoners. We also examine the ways in which prison staff dealt with such prisoners, bound as they were to enforcing the prison regime and discipline as well as attempting to ensure the health of their prisoner patients. We ask how far the management of mental illness in prison aimed to mitigate harm to the institution rather than relieving the prisoner patient. In the concluding section, we focus on continuities, examining how changing mental health policies and shortages in alternative provision of care contributed to the accumulation of large numbers of mentally ill people in prison. The challenging conditions that prevail in prisons-overcrowding, poor standards of psychiatric services and staffing issues-have enabled prisons to defend the continued use of solitary confinement and reproduced an environment damaging to prisoners' minds. 


\section{Creating Troubled Minds in Prison: The System of Separate Confinement}

During the late 1830s, a new system of prison discipline was introduced to the British Isles, that of separate confinement or the 'Philadelphia system'. With the construction of Philadelphia's new prison, the Eastern State Penitentiary in 1829 , its architects and supporters were able to isolate prisoners from each other in a way that had not been attempted before (Gray 1847; Rothman 1998). When William Crawford, founder of the Society for the Improvement of Prison Discipline, was commissioned by the British government to report on American prisons and systems of discipline in 1833, he returned entranced with the 'Philadelphia system'. An equally fervent advocate of separate confinement was Reverend William Whitworth Russell, who in 1830 was appointed Chaplain to Millbank Penitentiary that had opened in 1816 as a showcase government prison with separate cells. In this position, Russell established great power as he directed the prisoners' moral and religious education and undertook individual cell visits. In 1831 and again in 1835, Russell gave evidence to Select Committees on prison reform advocating single cellular confinement, and agreeing with Crawford on the superiority of the separate system as exemplified in Philadelphia.

What attracted both men to separate confinement was its apparent ability to produce genuine reform and repentance, based as it was on the rigorous separation of prisoners from each other, and its emphasis, through moral training, religious exhortation and individual cell visitations, on inspiring reflection and redemption. In addition to being spiritually and morally reformative, it was also penal and imposed a fierce discipline on both its inmates and the prison officers. Crawford and Russell, who were appointed prison officers for London in 1835, refuted warnings of the risks the regime posed to the mental health of prisoners. At Eastern State Penitentiary, not only did separation appear to produce higher rates of insanity but also increased mortality amongst the prison inmates (Charleroy and Marland 2016, p. 142). Following his visit to Eastern State Penitentiary, its most famous critic Charles 
Dickens condemned the regime in his American Notes, published in 1842, describing the prisoners as 'dejected' and 'broken hearted' (Wilson 2009, p. 290). An editorial in the London Times, which ran a long-standing campaign against the importation of the separate system to England, predicted that insanity would be a 'probable', even 'inevitable', outcome of the Pentonville regime (The Times, 1 May 1841).

Despite such opposition, Pentonville Model Prison in London introduced separate cellular confinement in its most extreme form in 1842. Prisoners were confined in their cells alone and in silence for 23 hours out of 24, where they worked, ate and slept. Movement through the prison to attend chapel, where they sat in separate stalls, to take exercise and to attend classes, was rigorously controlled and prisoners were compelled to wear hoods to conceal their identity. Pentonville's carefully selected prisoners were to be first offenders in good health, aged between 18 and 35, fit and able to withstand the force of what was widely regarded as a testing regime and experiment. The prison chaplains, meanwhile, were 'central actors' in enforcing and superintending this system of discipline, through their sermons, management of the schoolmasters, and particularly their individual and frequent cell visitations (Forsythe 1987, p. 45). Prisoners were to endure this system of discipline for 18 months prior to transportation (Cox and Marland 2018, p. 84).

The predictions of Pentonville's critics proved accurate. Rather than producing the anticipated repentance, reform and improvement of the mind, in practice, Pentonville's early years were marked by high incidences of mental breakdown among the prisoners, alarming cases of delusion, hallucination, panic, depression, anxiety and morbid feelings. In 1851, eminent psychiatrist Dr. Forbes Winslow, explained that, despite aiming to exclude mentally ill prisoners, $1.4 \%$ of Pentonville's inmates were suffering from mental illness compared with $0.25 \%$ of the general population (Winslow 1851, p. 359). Peter Laurie, President of Bethlem Asylum, described Pentonville as a 'disgrace' and complained to The Times that 40 prisoners had been sent from Pentonville to Bethlem by 1847, 'the direct result of the separate system' (The Times, 11 January 1847). 
The separate system was quickly adopted in other convict and local prisons in England and extended to most prisons in Ireland from 1850 , even as it was being partly dismantled in Pentonville, where the length of separation was reduced after the sudden deaths of Crawford and Russell in 1847, to 12 months in 1848 and 9 months by 1853 (Henriques 1972, p. 86). Yet, responses varied in individual prisons. In 1856, a parliamentary review of the disciplinary systems in place in English and Irish prisons found that many prisons, including Reading, Bedford, Bath, Belfast, Kilkenny, Mountjoy and Pentonville, 'fully carried out' the separate system, while in others, implementation was partial or completely absent (Separate Confinement 1856 [163]). In 1853, Reverend John Field, Chaplain to Reading Gaol and a strong advocate of the separate system, declared to the Visiting Justices that 'I should... deeply lament both for the sake of Society and the Souls of Men that it should be subverted and abandoned, or even be modified as to impair its efficiency' (Berkshire Record Office, Q/S0 24, 17 October 1853, p. 143). Elsewhere, prison governors, medical officers and chaplains were more apprehensive about the impact of separation. Wakefield's prison officers expressed their reservations in 1847, its chaplain concluding that 'there appeared little doubt that cases of mental delusion might be attributed to the separate system'. Wakefield introduced modified dietary and exercise regimes, and allowed prisoners more outdoor exercise, which was claimed to reduce their mental stress (Wakefield Record Office Q/S 10/56, p. 98; Jebb 1852, p. 9). A number of other chaplains felt compelled to express doubt about the effectiveness of separate confinement. The chaplain of Spike Island Prison in Cork, Reverend Charles Gibson, described the cellular prison in 1863 as 'a delicate piece of machinery which no unskilful hand should touch. A few more turns of the screw, and you injure both the body and mind of the prisoners' (Gibson 1863, p. 69).

By the early 1850 s, official reports were casting doubt on the initial evidence that had led to the advocacy of separate confinement. Though instrumental in extending the separate system to Mountjoy Convict Prison, Dublin, opened in 1850 and designed according to the Pentonville model, Surveyor-General of Prisons and Pentonville's architect, Col. Joshua Jebb, suggested in 1852 that Crawford's enthusiasm 
after his visit to the Eastern State Penitentiary had been based on 'slender data', and that Crawford's assertion that the discipline 'would have no unfavourable effect on the mind or health' might be unfounded (Carroll-Burke 2000, pp. 56-57; Jebb 1852, p. 5).

In preparation for the introduction of the separate system to the new 'model' prison at Mountjoy, Henry M. Hitchins, Inspector of Government Prisons in Ireland, had visited Pentonville in January 1850. Reporting back, Hitchins noted the almost 'universal rejection of the 'purest' form of the separate system as too severe, affecting both the mental and physical condition of the convict and tending to stupefy'. Long periods of separate confinement, he suggested, could 'produce a general debility of mind and body - this aggravating in the prisoners any previous predisposition which may have existed' (National Archives of Ireland (NAI) GPO/LB/12, pp. 35, 53). Hitchins advised the medical officer at Mountjoy, Dr. Francis Rynd, to extend the examination of prisoners on admission to include their 'mental' as well as their physical condition. Hitchins also commented on the 'dread' felt by the convict returning to his 'separate cell'. Nonetheless, he concluded that "separation should be the principle" upon which Mountjoy prison is to be conducted, yet that many details of Pentonville which being extreme are necessarily futile, may be safely avoided' (NAI GPO/LB/12, pp. 35, 53). Rynd relaxed the 'strict prison discipline', by increasing the amount of time for exercise, and altering the diet and type of labour carried out in prisoners' cells. In 1851, he claimed that the absence of cases of mental disease in that year was a result of these modifications, in particular, his decision to provide 'sufficient occupation of the minds of prisoners' (Inspectors of Government Prisons in Ireland 1852, p. 54).

\section{Managing Bedlam in the Late Nineteenth- Century Prison}

Statements of this kind set the tone for the second half of the nineteenth century. Prison administrators, medical staff and the chaplains regularly voiced reservations about the separate system for its damaging 
effects on the mind and failure to reform. Yet, it prevailed. This is not to say that it was applied uniformly and with equal force in all prisons. Smaller prisons were ill adapted to implement separate confinement, while conditions of overcrowding hampered its imposition elsewhere. Some prisons would moderate or adapt separate confinement, and in Ireland more generally, the role of the chaplains as enforcers of moral reform was curtailed, as they exerted little control over the schoolmasters. Yet, the separate system would form the model and ideal for prison design and discipline throughout the nineteenth century. By 1850 , Pentonville had inspired ten new English prisons to be built on the same model, and ten others had converted to the separate system, while in Ireland, by 1856, approximately one third of convict and local prisons, were either built or adapted for the separate system (Ignatieff 1978, p. 197; Separate Confinement 1856). ${ }^{3}$

Following the nationalisation of the prison system in England and Ireland in the late 1870 s, prison regimes became harsher and support for cellular separation as a highly efficient and deterrent system strengthened (Forsythe 1991). Interest in imposing rigorous punishment and maximising control overrode the ideals of facilitating reflection and reformation amongst prisoners. As Miles Ogborn has argued, 'The terrors of solitude remained in place as a deterrent, alongside an increased emphasis on hard labour', once the system of transportation was dismantled and replaced by enforced labour (Ogborn 1995, p. 304).

During the second half of the nineteenth century, the presence of large numbers of mentally ill prisoners and the management of mental illness in prison were becoming a burdensome reality. It threatened the viability and success of separate confinement and hampered the smooth governance of prisons. Medical officers, chaplains and other prison officers were preoccupied on a daily basis with dealing with mentally ill prisoners, subduing their efforts to self-harm, commit suicide or to commit acts of destruction or violence. Already by the mid-1840s, Pentonville's medical officers and chaplains were reporting multiple cases of mental breakdown, some of whom were transferred to the infirmary for treatment, while others were retained under observation in their cells. While resisted by prison authorities keen to mask the extent of mental disorder in the prison, removals to Bethlem occurred on a regular basis (Cox and Marland 2018). 
While many prison medical officers were reluctant to blame the system of separate confinement for cases of mental illness, they asserted that prisons were becoming repositories for inmates already suffering some form of 'mental weakness'. Dr. John Campbell noted that, by 1855 , he was dealing with over 80 weak-minded prisoners at Dartmoor Prison's Invalid Depot, a figure that increased to 126 by 1860 (Hardy 1995, p. 71). In his 1857 review of medical officers' reports of convict prisons, Walter Crofton noted 'We have... in our prisons a class of prisoners in a state of mind verging between reckless viciousness and insanity, generally of deficient intellectual powers, of great irritability of temper and totally destitute of self-control ... they cannot be admitted with safety into association without proper treatment and in the lunatic cell they become confirmed and incurably insane' (Directors of Convict Prisons in Ireland 1858, p. 10). In 1873, the medical officer at Spike Island, Dr. Patrick O'Keeffe, estimated that there were 40 weakminded inmates in the prison, many of whom had been transferred from Mountjoy (Royal Commission 1884-1885 [C.4233] [C.4233-I], p. 28). Their accumulation prompted debate within the General Prison Board as to whether a prison modelled on Woking Invalid Prison should be established in Ireland (NAI 1874). Towards the end of the century, the same situation in England prevailed with regard to the pressure of numbers. Brixton Prison's Medical Officer noted in 1882 that he did not have enough cell accommodation for troublesome mental cases (Hardy 1995, p. 74). By 1894, Holloway Prison, with a large turnover of inmates, including many on remand, was receiving between 3 and 13 cases of suspected mental illness daily; its medical officers noted this increased workload and their obligation to examine such prisoners several times to assess their mental condition (McConville 1995, p. 299).

As Martin Weiner has argued, 'penal Benthamism', that influenced much nineteenth-century policy and practice, incorporated the 'humanitarian' (that the 'ordinary condition' of convicted prisoners should not allow gratuitous physical suffering or danger to life and health) and the 'punitive', 'the rule of severity' and 'less eligibility'. The care of prisoners was measured against the 'scarce good' of health care for the general population, and produced an ongoing dilemma in prison healthcare provision (Weiner 1995, pp. 47-48). The constraints of 'dual loyalty', an effect of prison medical officers' complex role in both caring 
and lobbying for prisoners' health and supporting the disciplinary procedures of the prison, produced particular tensions when dealing with mentally ill prisoners (Sim 1990). While prison doctors certainly built up a good deal of practical experience in dealing with insanity, they normally had little in the way of specialist training. Their emphasis remained on diagnosis-largely sorting out the mad from the sanerather than treatment, on minimising the impact of mentally ill inmates on prison regimes, on damage limitation and preserving the reputation of the prison.

Prison medical officers saw the challenge of weeding out prisoners who were 'malingering' or feigning in order to achieve an amelioration of conditions as one of their principal duties, an aspect of their work that highlights tensions between care and discipline. Prisoners believed to be feigning could be harshly punished, beaten, deprived of food or placed in punishment cells. Towards the end of the century, prison medical officers also asserted that they were compelled to deal with an overwhelming range of mental afflictions, from 'simple weakness of the intellect to well-marked lunacy' and to 'contend with aggravated, chronic and intractable disease from hereditary disposition or constitutional degeneracy, the result of intemperate and vicious habits' (Campbell 1884, p. 73). Reporting on his experiences as Medical Officer at Woking Invalid Prison, Campbell observed that some prisoners 'display a marked degree of dullness or stupor; others sharpness and cunning more allied to the tricks of monkeys than the acts of reasonable men' (Campbell 1884, p. 73). Even in what he describes as the 'more favourable or hopeful cases', he pointed out that 'it must be remembered that we had to deal with lunatics that were also criminals, and it was sometimes difficult to discriminate between these two elements of character' (Campbell 1884, p. 86).

Dr. Robert McDonnell, Mountjoy's medical officer in the 1860s, expressed similar opinions and several other prison medical officers echoed these views during the hearings of the 1884 Royal Commission on Irish Prisons. Dismissing allegations that the Irish local prison system was intentionally cruel or systematically harsh, the commissioners justified instances of the excessive punishment of refractory prisoners on the basis that their 'mental condition may be described as borderland 
between sanity and insanity' (Royal Commission 1884-1885 [C.4233] [C.4233-I], p. 14).

While Campbell, O'Keeffe and others argued that some mentally ill prisoners were deserving of pity and that for some their illness had been caused by separate confinement, many prison officials denied this relationship. In 1896, Pentonville's medical officer, Dr. John Baker, argued that the number of insane in the prison system was exaggerated, and that ' $[T]$ he form of insanity in many cases is conclusive evidence that mental defect existed before reception into prison'. He, however, acknowledged that he had met with isolated cases where there was reason to believe that the prisoners' environment had adversely affected them, including cases of 'delusional insanity, probably due to the prolonged process of introspection, almost inseparable from cellular confinement'. 'These cases', he concluded, 'are few and far between' (Baker 1896, pp. 295, 301, 302).

Despite Baker's protestations, the number of cases of mental illness in prison continued to increase. In a memorandum on insanity in prisons in 1895, Dr. J. H. Bridges, acknowledged that 'among the prison population the ratio of insanity arising among persons apparently sane on admission is not less than three times as great as that amongst the general population of corresponding ages' (Gladstone Committee 1895, pp. 290-291). A year earlier, Reverend William Morrison, chaplain at Wandsworth Prison between 1887 and 1898, had argued that the severe and highly deterrent regime operating in prisons by the 1890s was responsible for driving prisoners mad and for further debilitating others who were constitutionally weak. He asserted that rates of insanity in local prisons had doubled between 1875-1877 and 1890-1892, as penal discipline became harsher, from 113 per 100,000 to 226 per 100,000 compared with 8 per 100,000 in the general population (Morrison 1894, p. 468).

Prisoner authors provide first-hand accounts of what they saw as the uselessness of many prison doctors, though a handful were positive about their own medical care or the efforts of the medical staff to improve the health of their prisoner patients more generally. Usually educated and more privileged than the majority of their fellow prisoners, these authors undertook to speak for them in many cases, and 
underlined the detrimental impact of a prison system that failed either to reform or treat. The nineteenth-century prison population was made up largely of impoverished men, with women accounting for around $20-25 \%$ of the prison population and those prosecuted by courts for minor offences (Johnston 2015, p. 122; Quinlan 2011, pp. 33-34). By the 1850 s and 1860 s, the label 'criminal class' had taken root, especially in urban areas and notably with regard to Irish communities, though social commentators, such as Henry Mayhew, asserted that many of the poor, while destitute, dirty and uneducated, were honest and industrious (Johnston 2015, pp. 26-27).

In particular, prisoner memoirs emphasised two issues related to mental breakdown. They described what they saw as the iniquity of the system of separate confinement, which was roundly condemned by almost all prison writers. They also highlighted the sluggishness of prison staff in responding to cases of mental illness and delays in receiving adequate treatment. While Dr. John Campbell claimed that he dealt with his patients with the greatest of consideration, one of his patients George Bidwell, referred to his 'inexpressible hatred and contempt' of all the prisoners he treated (Campbell 1884, p. 58; Bidwell 1895, p. 511). Oscar Wilde described prison doctors as ignorant men. The pathology of the mind is unknown to them. When a man grows insane, they treat him as shamming.' 'The production of insanity' was, he asserted, if not the object of separate confinement, 'certainly its result' (Wilde 1990). In correspondence with the Irish General Prisons Board, prisoners reported instances of medical officers' neglect and the inferior standard of treatment in prison hospitals, but these cases were often dismissed as malicious and unfounded.

Delays in treatment - and the frequent removal of prisoners between institutions - were also highlighted in prison records. Often, this was related to efforts to reach decisions on whether or not a prisoner was feigning, or to cases where the prison staff were uncertain as to whether a prisoner was mad or disruptive. Thomas Bourke was aged just 15 when in April 1853 he was convicted of burglary and robbery. He was first sent to Philipstown Prison, Co. Offaly, an invalid depot and associated labour prison, and then moved to Mountjoy in July 1855, where he was placed on the separate system. There, he repeatedly broke the 
rule of silence, assaulted wardens and his fellow prisoners, destroyed his cell, feigned suicide and refused to work. Frequent punishmentseither by placing Bourke on a reduced diet, stopping his meals altogether, or confining him a dark cell—did not improve his behaviour. He was transferred to the associated labour prison at Spike Island, back to Mountjoy for a second period in separation, and then back again to Philipstown Prison. He was finally transferred to Dundrum Criminal Lunatic Asylum, Dublin, in 1860 after seven years in various prisons (NAI, GPO/PN/4 Reg. No. 1742.). The prison system revealed an inability to assess such prisoners and offer treatment and, in many cases, their responses are likely to have led to deterioration in the mental health of their charges. Yet more troubling, even when the damage caused by separate confinement was acknowledged, it was described as a form of collateral damage. As Dr. William Guy, Medical Superintendent of Millbank Prison (1859-1869), and a leading authority on prison medicine, observed:

Our system of separate confinement does not appear to affect the mind injuriously. I do not mean to say that a prisoner who comes into prison upon the verge of unsoundness of mind, might not develop into full unsoundness in that time, partly because of the separation; but I am of opinion, also that a prisoner should expect that this may happen to him, and that the possibility of unsoundness must be taken into account as one of the results of his being in prison at all. (Select Committee 1863 (499), IX, p. 370)

\section{Continuities and the Recreation of Bedlam}

During the nineteenth century, the removal of prisoners to asylum care was frequently resisted, even though provisions were in place for such removals if a prisoner was certified insane after committal, and many prison doctors, like Campbell, urged the transfer of mentally ill prisoners from the prison estate, even when these were incarcerated in specialised invalid prisons like Woking. Such prisoners were difficult to deal with, impossible to help and disturbed the other inmates, according to 
Campbell (1884). In the twentieth century, while taking very different routes in England and the Republic of Ireland, the reluctance to move mentally ill prisoners out of prisons was transformed into an inability to have prisoners moved on to specialist hospitals due to a lack of alternative provision.

Following the findings of the (1895) Gladstone Report on prisons, there were changes in responses to mentally ill prisoners; even though the Report's initial emphasis on insane prisoners was diluted and the relationship between criminality and mental illness left unresolved, the Report concluded that the separate system needed to be reformed. Toby Seddon (2007) has summarised changes in the twentieth-century English prison system with regard to mental health. Beginning in the early twentieth century, there were efforts to 'clear out' various categories of mentally ill prisoners, including the 'weak-minded', in order to focus on 'responsible prisoners'. During the 1920s and 1930s, psychological and psychoanalytical treatments impinged on approaches to mentally disordered offenders, with many doctors arguing that all crime had 'mental' origins. After the Second World War, psychiatric work in English prisons expanded, in what Seddon describes as 'the high-water mark of penal-welfarism and correctionalist crime control', though in effect most of the work with mentally ill prisoners was diagnostic (Seddon 2007, pp. 7, 34; Garland 2001, p. 34). Even at the start of the century, efforts to remove the 'weak-minded' from the prison system were limited by a lack of alternative institutional facilities, and, by the 1970s, shifts in mental health policy in England towards care in the community provision had led to the winding down of large Victorian asylums and to a steady decline in the number of psychiatric hospital beds. This lack of provision outside prisons was already observed in 1978, when J. H. Orr, Director of Prison Medical Services in England, described a situation where:

mentally disordered offenders are entering prisons not because the net is insufficiently wide or discriminating but because hospital places are not forthcoming. It is an irony that under the Mental Health Act 1959... we imprison more mentally disordered offenders than under the old Lunacy and Mental Deficiency Acts. In 1931 (when the average prison 
population was about 12,000) 105 sentenced prisoners were recognized as suffering from mental illness and transferred to hospital. In 1976 the number of sentenced prisoners recognized as suffering from mental illness was more than double this figure, but the number transferred...less than half. (Orr 1978, p. 195)

Those experiencing mental health problems in prison became more likely to circulate between hostels and homelessness, with short stays in hospital rather than long-term treatment in a mental hospital (Seddon 2007, p. 35).

Until the late 1960s, the prison estate and prison population in the Republic of Ireland was small. Penal policy had 'effectively calcified' (Kilcommins et al. 2004, p. 24) while prison psychiatric services were almost non-existent (O'Sullivan and O’Donnell 2012, p. 21). Provision outside the prison was also under severe pressure; there was a threefold increase in admissions to psychiatric hospitals between 1948 and 1960 (Walsh and Daly 2004, p. 31). Yet, prisons remained heavily dependent on these overcrowded hospitals as well as on the Central Mental Hospital, Dundrum, for psychiatric services. In 1965, there were 102 'patients in custody' in Dundrum and a further 95 in the District Mental Hospitals (Commission on Mental Illness 1966, p. 91). The late twentiethcentury policy shift away from the institutional treatment of psychiatric patients coincided with the explosion in the Irish prison population. By the 1980s, as psychiatric facilities outside prison shrunk further, prisoners could only be accepted at Dundrum, while prisons continued to be criticised for failing to provide psychological and psychiatric services (O'Connor and O'Neill 1990, p. 118; 1991, p. 112). One of the striking features of late twentieth-century prisons has been the build-up of mentally disordered offenders; in 1993, it was estimated that $5 \%$ of prisoners in the Republic were mentally ill and there was a waiting list for admission to Dundrum (Hegarty 1993).

The problem of dual loyalty has persisted, as 'rather than operating within an independent set of discourses designed to care for the confined' prison doctors 'were integral to the control and disciplinary apparatus of the modern prison' (Sim 2002, p. 301; Reilly 2016, p. 14). In both England and Ireland, prison doctors continued to be criticised 
for their lack of training in psychiatry, particularly when they end up treating large numbers of prisoners with psychiatric disorders, while prisons have been censured for failing to provide access to psychiatric consultations and services on an in-patient basis (Crowley 2003, p. 47). In 1990-using a headline similar to the report cited at the start of this essay - the Guardian declared how 'Bedlam Lives On'. This was in response to Chief Inspector of Prisons Judge Stephen Tumin's report on Brixton Prison, which referred to the harsh conditions for mentally disturbed prisoners and the high number of suicides and asserted that the prison was failing in its duty to look after inmates with humanity. Judge Tumin was particularly critical about the crowded psychiatric wing at a time when Brixton housed more psychiatric prisoners than any other prison in the UK and possibly Europe. The proposed stop-gap in his view was the creation of specialist units in prison, but the solution lay with courts referring people with mental health problems for treatment in NHS hospitals. The 'quality of the medical treatment... has long been scandalously bad' with doctors part of the 'disciplinary structure of prison' (Guardian 14 December 1990; Ryan 1995, p. 72).

Specialist psychiatric units for prisoners within or outside prisons were slow to emerge in Ireland. A ten-bed high-support unit was opened at Mountjoy prison in 2010. However, Dundrum continued to be the only psychiatric hospital to accept prisoners ${ }^{4}$ (Crowley 2003, p. 47). The potentially fatal consequences of the Irish Prison Service's over-reliance on Dundrum, alongside the gaps in in-patient psychiatric arrangement services, were revealed in July 2006 when Gary Douch, a prisoner in Mountjoy Prison, died following a brutal assault by fellow prisoner Stephen Egan. Both had been confined in a holding cell in the B-Base of the prison. In the preceding months Egan, who had a long history of psychiatric disorders and violent behaviour, was repeatedly transferred between Dundrum, Mountjoy and Cloverhill prisons, reproducing the movements of prisoners between institutions in the nineteenth century. The subsequent investigation highlighted serious failures in the management of prisoners with psychiatric disorders (McMorrow 2014).

While the separate system has been long abandoned, elements of it are still found today in solitary confinement, which, whether imposed for reasons of restraint or punishment, for the protection of 
prisoners, or, most likely in the UK context, because of a shortage of staff and facilities, causes or exacerbates mental breakdown in prisoners. A recent report on Wormwood Scrubs Prison in London revealed that many prisoners had less than two hours a day 'unlocked' and all had only 40 minutes of outdoor exercise a day, less than the time prescribed at Pentonville in 1842 (HM Prisons Inspectorate 2016). Deep Custody, produced by the English Prison Reform Trust, highlighted the 'toxic' effects of segregation, 'social isolation, reduced sensory input/ enforced idleness and increased control of prisoners' (Shalev and Edgar 2015, p. 91). Yet, solitary confinement continues to be used. Despite the Irish Prison Service's commitment to reduce solitary confinement and restricted regimes, in April 2017, 430 prisoners were on restricted regimes, defined as a minimum of 19 hours locked up in cells (Irish Penal Reform Trust 2017, p. 17).

Recent initiatives have attempted to improve poor psychiatric provision within prisons; in-reach psychiatric teams have been introduced to prisons in England and Ireland and a diversion scheme was developed at Cloverhill remand prison in Ireland. While often the subject of criticism, prison medical officers and prison medical services have over the last few decades become more open and engaged, joining in critiques of prison medical services and highlighting obstacles to the adequate provision of care for their prisoner/patients. In parliamentary inquiries undertaken in the mid-1980s in the UK, prison medical officers reflected openly on dual loyalty and expressed an eagerness to work more closely with rest of the medical profession (Duvall 2018).

This shift towards collaboration tended to replace, Duvall has argued, the assertions-similar to those of their nineteenth-century predecessors - that prison medical officers have a particular knowledge and special experience valuable in treating mentally ill prisoners (Duvall 2018). In England, in 2013, responsibility for commissioning all healthcare services for prisoners was transferred to the NHS, but as prison populations continue to grow, so too do the numbers of people in prison who report having mental health issues, and efforts to achieve an equivalent health service are hampered by the prison environment and lack of services outside of prison. This approach, however, has been accepted as a model for good practice and other jurisdictions 
have lobbied for the integration of prison medical services with general health systems. In 2016, Judge Michael Reilly, Inspector of Prisons, produced a report on prison health care in the Republic of Ireland, which strongly advocated for the incorporation of prison health care into the Irish Health Service Executive (Reilly 2016).

As the management of prisoners with mental disorders continues to attract regular reports, the attention of the media and the concern of prison reform organisations, history can be drawn on to highlight continuities in terms of the challenges facing prisons in dealing with mentally ill prisoners. It reveals the detrimental impact of solitary confinement and the negative and sometimes alarming consequences of leaving mentally ill prisoners to languish in prison. History provides examples and narratives of the impact of prison regimes on mental health and the obstacles in providing effective treatment, many resulting from ongoing tensions between care and discipline, and punishment and treatment. It also provides a final sobering conclusion that in the 175 years since the introduction of the modern prison system, little has changed in terms of the high rate of imprisonment of mentally ill people and the detrimental effects of prison on mental health.

\section{Notes}

1. Bedlam or Bethlem Hospital is London's oldest institution to specialise in treating mental illness, admitting insane patients from the fourteenth century onwards. Both famous and at times infamous, its popular designation, Bedlam, became synonymous with madness itself.

2. For a full account, see DeLacy (1986, chap. 5).

3. In 1854, the Directors of Convict Prisons for Ireland was established with Walter Crofton as Chair. Crofton implemented the 'mark' or 'Irish' system adapted from Alexander Maconochie's New South Wales system. At Mountjoy, convicts were initially placed on the separate system for 8 months. Then, convicts earned marks through work and good behavior and, if successful, were transferred to an intermediate, associated prison. Marks could also be removed and convicts demoted (CarrollBurke 2000, pp. 103-104). 
4. A national forensic hospital and intensive care units for Cork, Galway and Portrane is planned for Portrane, Co. Dublin to replace the Central Mental Hospital, Dundrum (Kelly 2017, pp. 266-267).

\section{Bibliography}

Baker, J. (1896). Insanity in English local prisons, 1894-95. Journal of Mental Science, 42(177), 294-302.

Berkshire Record Office Q/S0 24, Sessions Order Book, April 1853-July 1855, Chaplain's Report, General Quarter Sessions.

Bidwell, G. (1895). From Wall Street to Newgate. Hartford, CT: Bidwell Publishing.

Bradley, L. (2009). The Bradley report. Lord Bradley's review of people with mental health problems or learning disabilities in the criminal justice system. London: Department of Health.

Campbell, J. (1884). Thirty years' experience of a medical officer in the English convict service. London: T. Nelson and Sons.

Carroll-Burke, P. (2000). Colonial discipline: The making of the Irish convict system. Dublin: Four Courts Press.

Charleroy, M., \& Marland, H. (2016). Prisoners of solitude: Bringing history to bear on prison health policy. Endeavour, 40(4), 141-147.

Commission of Inquiry on Mental Illness. (1966). 1966 Report. Dublin: Stationary Office.

Cox, C., \& Marland, H. (2018). "He must die or go mad in this place": Prisoners, insanity and the Pentonville model prison experiment, 1842 1852. Bulletin of the History of Medicine, 92(1), 78-104.

Crowley, F. (2003). Mental illness: The neglected quarter. Dublin: Amnesty International.

DeLacy, M. (1986). Prison reform in Lancashire, 1700-1850: A study in local administration. Stanford, CA: Stanford University Press.

Directors of Convict Prisons in Ireland. (1858). Fourth annual report of the Directors of Convict Prisons in Ireland 1857. Dublin: HMSO.

Duvall, N. (2018). "From defensive paranoia to ... openness to outside scrutiny": Prison medical officers in England and Wales in the 1970s and 1980s. Medical History, 62(1), 112-131.

Forsythe, W. J. (1987). The reform of prisoners 1830-1900. Sydney and London: Croom Helm. 
Forsythe, W. J. (1991). Centralisation and autonomy: The experience of English prisons 1820-1877. Journal of Historical Sociology, 4(3), 317-345. Garland, D. (2001). The culture of control: Crime and social order in contemporary society. Oxford: Oxford University Press.

Gibson, C. B. (1863). Life among convicts (Vol. 1). London: Henry Colburn. Gladstone Committee. (1895). Report from the Departmental Committee on Prisons, 1895 [C.7702] [C.7702-I].

Gray, F. (1847). Prison discipline in America. Boston: Charles C. Little and James Brown.

Guardian. (1990, December 14). Bedlam lives on.

Hardy, A. (1995). Development of the prison medical service. In R. Creese, W. F. Bynum, \& J. Bearn (Eds.), The health of prisoners (pp. 59-82). Amsterdam and Atlanta, GA: Rodopi.

Hegarty, T. (1993, March 24). Study finds 5\% of prison inmates are mentally ill. Irish Times.

Henriques, U. R. Q. (1972). The rise and decline of the separate system of prison discipline. Past and Present, 54(1), 61-93.

HM Prisons Inspectorate. (2016). Report of announced inspection of HMP Wormwood Scrubs 30 November-4 December 2015. Available at: https:// www.justiceinspectorates.gov.uk/hmiprisons/wp-content/uploads/ sites/4/2016/04/Wormwood-Scrubs-web2015.pdf. Accessed 28 Nov 2017.

Howard, J. (1780/1784). The state of the prisons in England and Wales. Warrington: William Eyres.

Humphreys, J. (2013, September 16). The prison trap. Irish Time.

Ignatieff, M. (1978). A just measure of pain: The penitentiary in the industrial revolution 1750-1850. London and Basingstoke: Macmillan.

Inspectors of Government Prisons in Ireland. (1852). Annual report for the year ended 31st December 1851, 1852-1853.

Irish Penal Reform Trust. (2017). Submission to the second periodic review of Ireland under the United Nations Convention against torture and other cruel, inhuman or degrading treatment or punishment. Dublin: Irish Penal Reform Trust.

Jebb, J. (1852). Report on the discipline and management of the convict prisons. London: HMSO.

Johnston, H. (2015). Crime in England 1815-1880. London and New York: Routledge.

Kelly, B. (2017). Hearing voices: The history of psychiatry in Ireland. Dublin: Irish Academic Press. 
Kilcommins, S., O’Donnell, I., O’Sullivan, E., \& Vaughan, B. (2004). Crime, punishment and the search for order in Ireland. Dublin: Institute of Public Administration.

Laurie, P. (1847, May 1). Letter to Editor. The Times.

McConville, S. (1995). English local prisons, 1860-1900: Next only to death. London: Routledge.

McMorrow, G. (2014). Report on commission of investigation into the death of Gary Douch.

Morrison, W. D. (1894). Are our prisons a failure? The Fortnightly Review, 61(April), 459-469.

National Archives of Ireland (NAI). GPO/LB/12, Letter Book: Letter from Henry M. Hitchins to Francis Rynd, 14 February 1850.

National Archives of Ireland (NAI). GPO/PN/4, Philipstown Character Books, 1847-1862.

National Archives of Ireland (NAI). (1874). Chief Secretary's Office registered papers, $1874 / 4814$.

Neild, J. (1812). State of the prisons in England, Scotland and Wales. London: John Nichols.

O'Connor, A., \& O’Neill, H. (1990). Male prison transfers to the central mental hospital: A special hospital (1983-1988). Irish Journal of Psychological Medicine, 7(2), 118-120.

O'Connor, A., \& O’Neill, H. (1991). Female prison transfers to the central mental hospital: A special hospital (1983-1988). Irish Journal of Psychological Medicine, 8(2), 122-123.

Ogborn, M. (1995). Discipline, government and law: Separate confinement in the prisons of England and Wales, 1830-1877. Transactions of the Institute of British Geographers, 20(3), 295-311.

Orr, J. H. (1978). The imprisonment of mentally disordered offenders. British Journal of Psychiatry, 133(3), 194-199.

O'Sullivan, E., \& O'Donnell, I. (2012). Coercive confinement in postindependence Ireland: Patients, prisoners and penitents. Manchester: Manchester University Press.

Prisons (Separate Confinement). (1856). Abstract of a 'Return of the prisons in England and Ireland; distinguishing those in which the system of separate confinement is fully carried out', 163.

Quinlan, C. M. (2011). Inside: Ireland's women's prisons. Past and present. Dublin: Irish Academic Press.

Reilly, M. (2016). Healthcare in Irish prisons. Nenagh: Inspector of Prisons. 
Rothman, D. J. (1998). Perfecting the prison: United States 1789-1865. In N. Morris \& D. J. Rothman (Eds.), The Oxford history of the prison: The practice of punishment in Western society (pp. 100-115). Oxford: Oxford University Press.

Royal Commission on Prisons in Ireland. Vols I and II, 1884-1885 [C.4233] [C.4233-I].

Ryan, M. (1995). Lobbying from below: INQUEST in defence of civil liberties. London: Routledge.

Seddon, T. (2007). Punishment and madness: Governing prisoners with mental health problems. Abingdon: Routledge.

Select Committee. (1863). Select committee of House of Lords on state of prison discipline in gaols and houses of correction [Carnarvon committee], 1863 (499).

Shalev, S., \& Edgar, K. (2015). Deep custody: Segregation units and close supervision centres in England and Wales. London: Prison Reform Trust.

Sim, J. (1990). Medical power in prisons: The Prison Medical Service in England 1774-1989. Milton Keynes and Philadelphia: Open University Press.

Sim, J. (2002). The future of prison health care: A critical analysis. Critical Social Policy, 22(2), 300-323.

Sloan, A., \& Allison, E. (2014, May 24). "We are recreating Bedlam": The crisis in prison mental health services. Guardian.

The Times. (1841, January 11). Editorial.

Wakefield Record Office Q/S 10/56, Quarter Sessions Order Book, October 1846-April 1850.

Walsh, D., \& Daly, A. (2004). Mental illness in Ireland, 1750-2002: Reflections on the rise and fall of institutional care. Dublin: Health Research Board.

Weiner, M. J. (1995). The health of prisoners and two faces of Benthamism. In R. Creese, W. F. Bynum, \& J. Bearn (Eds.), The health of prisoners (pp. 44-58). Amsterdam and Atlanta, GA: Rodopi.

Wilde, O. (1990). To the editor of the Daily Chronicle, 27 May [1897] and 23 March [1898]. In I. Murray (Ed.), Oscar Wilde: The soul of man and prison writings. Oxford: Oxford University Press.

Wilson, D. (2009). Testing a civilisation: Charles Dickens on the American penitentiary system. The Howard Journal of Criminal Justice, 48(3), 280-296.

Winslow, F. (1851, March). Medical society of London: Prison discipline. Lancet, 357-360. 
Open Access This chapter is licensed under the terms of the Creative Commons Attribution 4.0 International License (http://creativecommons. org/licenses/by/4.0/), which permits use, sharing, adaptation, distribution and reproduction in any medium or format, as long as you give appropriate credit to the original author(s) and the source, provide a link to the Creative Commons license and indicate if changes were made.

The images or other third party material in this chapter are included in the chapter's Creative Commons license, unless indicated otherwise in a credit line to the material. If material is not included in the chapter's Creative Commons license and your intended use is not permitted by statutory regulation or exceeds the permitted use, you will need to obtain permission directly from the copyright holder.

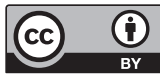

